\title{
Nota Editoral Temática \\ GT População, Espaço e Ambiente: 25 anos abrindo novas fronteiras do conhecimento
}

Os estudos sobre População, Espaço e Ambiente desenvolvidos pela demografia brasileira nasceram nos primeiros encontros da Abep, no final dos anos 1970. Os anais destes eventos trouxeram textos que abordam os principais temas de interesse da época, como a colonização e a exploração de recursos na Amazônia, a problemática urbana e a questão agrária no Brasil. No entanto, foi no início da década de 1990 que tais preocupações foram sistematizadas no âmbito de um Grupo de Trabalho (GT) específico, que surgiu a partir de uma iniciativa da diretoria da Abep e dos esforços dos primeiros demógrafos que incorporaram a preocupação ambiental nos seus trabalhos. Tal grupo, inicialmente denominado População e Meio Ambiente, não demorou muito para ampliar sua representatividade nos círculos acadêmicos, congregando outros pesquisadores de destaque.

As bases estavam lançadas para que, a partir dos anos 2000, a demografia brasileira passasse a dialogar intensamente com os mais variados temas ligados à questão ambiental. Novas gerações de pesquisadores se interessaram em explorar as interseções entre a demografia e os enormes desafios ambientais, em suas diversas escalas, contribuindo ativamente com as atividades do GT. Diversos interlocutores ampliaram as ações do grupo por meio de parcerias e esforços interdisciplinares. O GT mudou de nome em 2006 e passou a se chamar População, Espaço e Ambiente, em reconhecimento às novas tendências e possibilidades analíticas deste campo de pesquisa.

A questão ambiental evoluiu muito nas últimas décadas, incorporando outros problemas e preocupações a uma velocidade incrível. No mesmo ritmo, cresceram as possibilidades de contribuição da demografia com o tema numa perspectiva interdisciplinar. Se, por um lado, alguns assuntos tradicionais (dinâmicas rural e urbana, poluição, condições de vida, industrialização e ambiente, entre outros) continuaram a despertar o interesse dos estudiosos de população, espaço e ambiente, por outro, temas emergentes (ciclo de vida e dinâmica domiciliar em áreas rurais, população e consumo, população e mudanças climáticas, entre outros) não foram negligenciados pela demografia brasileira. Ainda, nos últimos anos, ferramentas computacionais gratuitas de geoprocessamento, novos pacotes estatísticos e as constantes novidades advindas da internet permitiram grandes avanços na integração de dados demográficos, socioeconômicos e ambientais. 
Em 2015, ano marcado por importantes eventos internacionais focados na discussão ambiental, com destaque para as negociações dos Estados Membros das Nações Unidas para os próximos 15 anos sobre os Objetivos de Desenvolvimento Sustentável (ODS) e a realização da Conferência do Clima (COP 21) em Paris, o GT População, Espaço e Ambiente comemora seus 25 anos de existência. Neste um quarto de século, o grupo debruçou-se para a abertura de novas fronteiras do conhecimento. Muito se fez desde a idealização do GT. Produções científicas e outras diversas iniciativas garantiram a estruturação, o crescimento e o amadurecimento do grupo enquanto formador de opinião e de conhecimento. Diante disso, as próximas linhas trazem um breve resgate de algumas das principais obras desenvolvidas com base no trabalho coletivo do GT nesses 25 anos.

A primeira coletânea de textos promovida pelo GT, intitulada População, meio ambiente e desenvolvimento: verdades e contradições, foi organizada por George Martine e publicada em 1993. A obra continua sendo de grande relevância, delineando as principais linhas de pensamento e de pesquisa do grupo, que se preocupava em diferenciar seus discursos do debate neomalthusiano, além de buscar soluções para os problemas emergentes no ambiente urbano. Em 2000, a obra População e meio ambiente, de Haroldo Torres e Heloísa Costa, atualizou esse debate, sintetizando o crescimento das elaborações teóricas e metodológicas do grupo, incorporando questões mais amplas.

Em 2007, a edição temática da Rebep (volume 24, número 2), com artigos específicos sobre o tema população, espaço e ambiente, foi decisiva para o sucesso e crescimento do GT. Nessa publicação observa-se a crescente massa crítica dedicada aos temas de escopo do grupo, com destaque para a avaliação dos processos de mudança no uso e ocupação da terra, principalmente em áreas de expansão de fronteira, e, novamente, as questões ambientais urbanas.

Em 2012, a revista internacional da Springer, Population and Environment, publicou um volume especial em memoria ao professor Daniel Hogan, com a participação de vários autores do GT e também de pesquisadores de outros países. Esta edição demonstra a influência e a importância de Daniel Hogan para a demografia ambiental brasileira e internacional, bem como sugere que sua missão profissional e de outros companheiros de GT está sendo muito bem cumprida, tendo em vista a nítida influência que pesquisadores brasileiros associados ao grupo passaram a exercer nos círculos internacionais nos últimos anos.

Neste mesmo ano, a publicação População e sustentabilidade na era das mudanças ambientais globais, lançada pela Abep, com edição de George Martine e co-organização de Ricardo Ojima, Alisson Flávio Barbieri e Roberto do Carmo, buscou estabelecer um diálogo não apenas com a comunidade científica, mas também com a sociedade de maneira geral. Para isso, a obra foi escrita com uma linguagem menos técnica, em capítulos curtos e com a participação de autores com diversos backgrounds de formação e atuação profissional.

Mais recentemente, a revista Espinhaço lançou em 2014 um número especial sobre o tema população, espaço e ambiente, reunindo os principais trabalhos produzidos pelo GT e apresentados no II seminário nacional organizado pelo grupo. Esta edição demonstra 
com clareza a ampliação das abordagens sobre o tema (mudanças ambientais, estrutura etária e consumo, recursos hídricos, vulnerabilidade socioambiental, entre outras), o intercâmbio com outros GTs da Abep e, também, o crescimento da comunidade interessada nestes estudos. Ademais, outros muitos livros e textos foram publicados nestes 25 anos de trajetória do GT, com base em iniciativas individuais ou parcerias entre membros do grupo e integrantes de outras associações.

Este número temático da Rebep celebra os 25 anos de existência do GT. Assim como o grupo, desde o seu nascimento, a revista se tornou muito mais influente com a nítida ampliação de seu nível de excelência, divulgação nacional e internacionalização. Esta edição é fruto da parceria do GT com o comitê editorial da revista, trazendo seis artigos inéditos, uma nota de pesquisa, três pontos de vista, uma resenha e uma divulgação de livro sobre as principais conexões entre a demografia e as questões ambientais contemporâneas.

É homenageado um passado repleto não apenas de publicações e crescimento acadêmico, mas, sobretudo, de história realizada por pessoas determinadas e perseverantes, seja na coordenação direta do GT, seja no apoio incansável às atividades do grupo. Um passado de alegrias e, também, de saudades daqueles colegas queridos que já se foram. Temos pela frente um futuro promissor que, certamente, trará grandes desafios teóricos e metodológicos para os integrantes do grupo, em que a busca por abordagens que tragam luz sobre as relações sociedade e natureza será presença constante.

Douglas Sathler, coordenador do GT César Marques, vice-coordenador do GT 